\title{
PENGANGGARAN KEUANGAN DAERAH YANG BERPIHAK PADA PEMENUHAN HAK-HAK PENYANDANG DISABILITAS DI KOTA SURAKARTA*
}

\author{
Y. Sri Pudyatmoko** dan Imma Indra Dewi**** \\ Bagian Hukum Administrasi Negara, Fakultas Hukum Universitas Atma Jaya Jalan Mrican Baru No.28 \\ Yogyakarta, 55281 \\ Bagian Hukum Bisnis, Fakultas Hukum Universitas Atma Jaya \\ Jalan Mrican Baru No.28 Yogyakarta, 55281
}

\begin{abstract}
Surakarta city has been succesful to become suitable city for Disable Persons. District financial budgeting policy in Surakarta City is able to accomodate the interest of disable persons. Budgetting policy for disable persons in Surakarta city is carried out by preparing budget for empowering disable persons and preparing supporting means which are usefull for disable persons. Budgetting is carried out by posting it into the allowance managed by The Ministry of labour and Transmigration, The Ministry of Education, Youth and Sport, The Ministry of Public Work, and also The Ministry of Transportation.
\end{abstract}

Keywords: budget, disabilities person, fulfilment of rights.

\section{Intisari}

Kota Surakarta telah berhasil menjadi Kota Layak Disabilitas. Kebijakan penganggaran keuangan daerah di Kota Surakarta mampu mengakomodir kepentingan penyandang disabilitas. Kebijakan penganggaran bagi penyandang cacat di Kota Surakarta dilakukan dengan menyediakan anggaran terhadap pemberdayaan kaum difabel maupun penyediaan sarana penunjang yang berguna bagi kaum difabel. Penganggaran dilakukan dengan memasukkan ke dalam belanja yang dikelola oleh Dinas Sosial Ketenagakerjaan dan Transmigrasi, Dinas Pendidikan Pemuda dan Olah Raga, Dinas Pekerjaan Umum, dan juga Dinas Perhubungan.

Kata Kunci: anggaran, penyandang disabilitas, pemenuhan hak.

\section{Pokok Muatan}

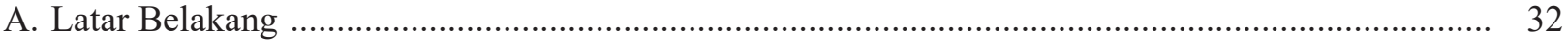

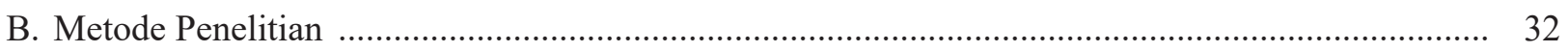

C. Hasil Penelitian dan Pembahasan ........................................................................................ 33

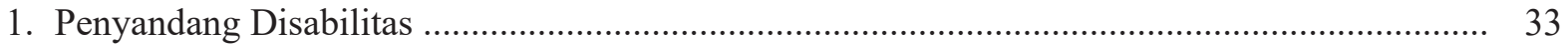

2. Urgensi Penyediaan Dana Bagi Penyandang Disabilitas ....................................................... 36

3. Penganggaran Bagi Pemenuhan Hak Penyandang Disabilitas di Kota Surakarta ..................... 38

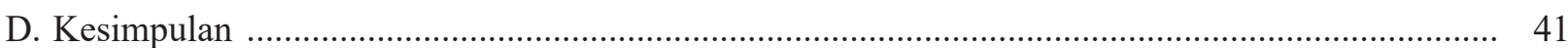

Penelitian Hibah Fundamental Dikti Tahun 2015.

Alamat korespondensi: pudy07@gmail.com.

****Alamat korespondensi: mbakyuimma@gmail.com. 


\section{A. Latar Belakang}

Secara konstitusional, Indonesia dalam Pasal 34 ayat (1) UUD 1945 pasca amandemen menentukan bahwa fakir miskin dan anak-anak yang terlantar dipelihara oleh negara. Selanjutnya pada ayat (2) UUD 1945 ditentukan bahwa Negara mengembangkan sistem jaminan sosial bagi seluruh rakyat dan memberdayakan masyarakat yang lemah dan tidak mampu sesuai dengan martabat kemanusiaan. Hal tersebut sejalan dengan Konvensi International Hak-Hak Penyandang Cacat dan Protokol Opsional Terhadap Konvensi (Resolusi PBB No 61/1061 tanggal 13 Desember 2006) dan telah disahkan sebagai UU No 19 Tahun 2011 tentang Pengesahan Konvensi Internasional Hak-hak Penyandang Disabilitas yang intinya menegaskan bahwa negara-negara pihak berkewajiban untuk menjamin dan memajukan pemenuhan semua hak asasi manusia dan kebebasan mendasar semua orang penyandang disabilitas tanpa diskriminasi atas dasar kecacatan mereka. ${ }^{1}$

Pemerintah Daerah Kota Surakarta telah menerbitkan Perda Kota Surakarta No 2 Tahun 2008 tentang Kesetaraan Difabel (Lembaran Daerah Kota Surakarta Tahun 2008 Nomor 2) dalam rangka mewujudkan jaminan dan perlindungan hak-hak penyandang disabilitas. Peraturan Daerah tersebut kemudian ditindaklanjuti dengan Perwal Kota Surakarta No 9 Tahun 2013 tentang Petunjuk Pelaksanaan Peraturan Daerah Kota Surakarta Nomor 2 Tahun 2008 Tentang Kesetaraan Difabel. Dengan hadirnya peraturan perundangan tersebut berhasil mengantar Kota Surakarta menjadi Kota Layak Disabilitas. Artinya dengan didukung oleh kedua peraturan tersebut Pemerintah Daerah Kota Surakarta berhasil memenuhi hak-hak penyandang disabilitas di antaranya berkaitan dengan penganggaran keuangan daerah. Kebijakan penganggaran keuangan daerah di Kota
Surakarta mampu mengakomodir kepentingan penyandang disabilitas yang disebut sebagai anggaran "kecacatan." Permasalahan kebijakan penganggaran yang berpihak pada pemenuhan hak penyandang disabilitas tersebut perlu mendapat perhatian terutama dari pembuat kebijakan. Hal ini merupakan sesuatu yang belum dapat dijalankan oleh daerah lain. ${ }^{2}$

Berkaitan dengan hal tersebut maka penelitian ini difokuskan pada analisis model kebijakan penganggaran daerah yang berpihak pada pemenuhan hak-hak penyandang disabilitas di Kota Surakarta. Bertitik tolak dari latar belakang di atas, maka permasalahan yang diangkat adalah bagaimana model kebijakan penganggaran keuangan daerah yang diterapkan di Kota Surakarta untuk menjamin pelaksanaan hak-hak penyandang disabilitas?

\section{B. Metode Penelitian}

Penelitian ini bertujuan untuk menganalisis model kebijakan yang berpihak pada pemenuhan hak penyandang disabilitas di Kota Surakarta. Menurut Soerjono Soekanto ${ }^{3}$ persoalan hukum (yuridis) berkaitan dengan proses legislasi, formulasi (substansi), implementasi dan eksekusi, sehingga dengan demikian penelitian ini dapat dikatakan atau termasuk penelitian yuridis. Dalam rangka menjawab masalah yang telah dirumuskan, maka dalam penelitian ini digunakan metode analisis data kualitatif. Penelitian ini memerlukan data primer dan data sekunder. Data sekunder diperoleh dari penelitian kepustakaan. Alat untuk mendapatkan data sekunder dengan studi dokumen. Data primer diperoleh dari penelitian lapangan, yaitu data yang diperoleh langsung dari responden dan narasumber. Lokasi penelitian Kota Surakarta dengan pertimbangan Kota Surakarta telah mampu memenuhi hak penyandang disabilitas dan

Hal tersebut ditegaskan pada bagian Pembukaan huruf $\mathrm{r}$ dan Pasal 4 Konvensi International Hak-Hak Penyandang Cacat dan Protokol Opsional Terhadap Konvensi (Resolusi PBB No 61/1061 tanggal 13 Desember 2006).

Pasal 8 Peraturan Daerah Kota Surakarta No. 2 Tahun 2008 tentang Kesetaraan Difabel (Lembaran Daerah Kota Surakarta Tahun 2008 Nomor 2). Lihat juga pada Pasal 3, Pasal 8, dan Pasal 25 ayat (2) Peraturan Walikota Surakarta Nomor 9 Tahun 2013 tentang Petunjuk Pelaksana Perda Kota Surakarta No.2 Tahun 2008.

Soerdjono Soekanto, 1986, Sosiologi Hukum, Universitas Indonesia, Jakarta, hlm. 67. 
dinyatakan sebagai Kota Layak Disabilitas. Teknik pengambilan sampel menggunakan purposive sampling. Adapun responden dalam penelitian ini adalah Badan Perencanaan Pembangunan Pemerintah Daerah, Dinas Sosial, Dinas Pekerjaan Umum, dan Dinas Pendidikan dan Olah Raga Kota Surakarta. Alat pengumpulan data dalam penelitian lapangan adalah kuisioner dan pedoman wawancara.

\section{Hasil Penelitian dan Pembahasan 1. Penyandang Disabilitas}

United Nation sebagai sebuah badan internasional telah mendorong lahirnya Convention On The Rights of Persons With Disabilities. Sebuah konvensi yang dilahirkan untuk menjunjung harkat dan martabat penyandang disabilitas. Konvensi inipun telah disahkan oleh Pemerintah Indonesia dengan UU No 19 Tahun 2011 tentang Pengesahan Mengenai Convention On The Rights of Persons With Disabilities. Dengan pengesahan ini maka seharusnya terjadi perubahan yang sangat signifikan bagi bangsa dan Pemerintah Indonesia dalam memperlakukan para penyandang disabilitas. Perubahan ini nampak pada terjadinya pergantian penyebutan terhadap penyandang cacat menjadi penyandang disabilitas. Namun dalam prakteknya tak semudah apa yang telah dinormakan. Berdasar pengalaman riset dan observasi yang telah dilakukan selama ini, ternyata penyebutan penyandang disabilitas masih debatable di kalangan masyarakat. Begitu banyak istilah yang masih dipertahankan dengan berbagai alasan dan landasan hukum. Meskipun pada intinya masyarakat sepakat untuk mengganti istilah penyandang cacat seperti yang diatur Undang-Undang No. 4 Tahun 1997 tentang Penyandang Cacat dan telah dikenal luas selama ini, tetapi beberapa kalangan masih belum dapat menerima sepenuhnya penggantian istilah menjadi penyandang disabilitas. Beberapa istilah masih dipertahankan oleh sebagaian masyarakat untuk menggantikan istilah penyandang cacat yaitu penyandang difabel dan berkebutuhan khusus, selain penyandang disabilitas sendiri.

Terminologi yuridis penyandang cacat diatur dalam Bab I Pasal 1 angka 1 Undang-Undang No. 4 Tahun 1997 tentang Penyandang Cacat sebagai berikut: "Setiap orang yang mempunyai kelainan fisik dan/atau mental, yang dapat mengganggu atau merupakan rintangan dan hambatan baginya untuk melakukan kegiatan secara selayaknya, yang terdiri dari penyandang cacat fisik; penyandang cacat mental; serta penyandang cacat fisik dan mental." Pengertian penyandang cacat juga ditemukan dalam PP No 43 Tahun 1998 tentang Upaya Peningkatan Kesejahteraan Sosial Penyandang Cacat. Pada intinya pengertian yang diberikan oleh Peraturan Pemerintah ini sama dengan pengertian penyandang disabilitas yang diatur dalam UU No. 4 Tahun 1997 tentang Penyandang Cacat. ${ }^{5}$ Dalam UndangUndang No 39 Tahun 1999 tentang Hak Asasi Manusia, penyandang disabilitas dikatagorikan sebagai kelompok masyarakat rentan yang berhak memperoleh perlakuan dan perlindungan lebih berkenaan dengan kehususannya. ${ }^{6}$ Dalam UndangUndang No. 11 Tahun 2009 tentang Kesejahteraan Sosial, ditegaskan bahwa penyandang disabilitas digolongkan sebagai bagian dari masyarakat yang memiliki kehidupan yang tidak layak secara kemanusiaan dan memiliki kriteria masalah sosial. ${ }^{7}$

Penyandang disabilitas dikualifikasi sebagai setiap orang yang mempunyai kelemahan/kekurangan fisik dan/atau mental, yang dapat mengganggu atau merupakan rintangan dan hambatan baginya untuk melakukan kegiatan kehidupan dan penghidupan secara wajar. Ketentuan tersebut diatur dalam Pasal 1 angka 5 Permen PU No. 30/

Pasal 1 angka 1 Undang-Undang Nomor 4 Tahun 1997 tentang Penyandang Cacat (Lembaran Negara Republik Indonesia Tahun 1997 Nomor 9, Tambahan Lembaran Negara Republik Indonesia Nomor 3670).

Pasal 1 angka 1 Peraturan Pemerintah Nomor 43 Tahun 1998 tentang Upaya Peningkatan Kesejahteraan Sosial Penyandang Cacat (Lembaran Negara Republik Indonesia Tahun 1998 Nomor 70, Tambahan Lembaran Negara Republik Indonesia Nomor 3754).

Pasal 5 ayat (3) Undang-Undang Nomor 39 Tahun 1999 tentang Hak Asasi Manusia (Lembaran Negara Republik Indonesia Tahun 1999 Nomor 165, Tambahan Lembaran Negara Republik Indonesia Nomor 3886).

Pasal 5 ayat (2) Undang-Undang Nomor 11 Tahun 2009 tentang Kesejahteraan Sosial (Lembaran Negara Republik Indonesia Tahun 2009 Nomor 12, Tambahan Lembaran Negara Republik Indonesia Nomor 3886). 
PRT/M/2006 tentang Pedoman Teknis Fasilitas dan Aksesibilitas Pada Bangunan Gedung dan Lingkungan. Secara harafiah kata cacat merujuk pada kekurangan atau keburukan, ketidaksempurnaan yang lebih tepat ditujukan untuk benda mati. Cacat sebagai kata benda bermakna kekurangan yang menyebabkan nilai atau mutunya kurang baik atau kurang sempurna (yang terdapat pada badan, benda, batin, atau akhlak). Cacat dipadankan juga dengan lecet, cela, atau aib. ${ }^{8}$ Berdasar pada makna harafiah kata cacat tersebut dapat dikatakan bahwa cacat dimaknai sebagai sesuatu yang bermakna negatif. Hal ini tentunya tidak tepat untuk disandangkan pada manusia, karena manusia adalah cipataan Tuhan yang sempurna. Tuhan tidak menciptakan manusia yang rusak dan kondisi manusia tidak dapat dikatakan sebagai aib.

Dampak dari penggunaan istilah penyandang cacat yang nota bene bermakna negatif, penyandang disabilitas sering mengalami diskriminasi dan termarjinalkan, terutama dalam kaitannya dengan kebijakan publik. Penyandang disabilitas sering dipandang sebagai obyek bukan subyek, sehingga tidak mendapatkan prioritas dalam pembentukan dan implementasi kebijakan publik. Dengan demikian penggunaan istilah penyandang cacat bertentangan dengan jiwa penghargaan dan menjunjung tinggi harkat dan martabat manusia. Hal ini tentu bertentangan dengan semangat penghargaan terhadap harkat dan martabat manusia yang dijunjung tinggi Bangsa Indonesia yang telah ditetapkan dalam undang-undang bahkan undangundang dasarnya.

Memperhatikan makna cacat yang lebih banyak berkonotasi negatif dan begitu besarnya dorongan perjuangan kesetaraan hak penyandang disabilitas sebagai warga negara Indonesia maka mulailah dimunculkan istilah lain untuk menggantikan istilah cacat. Diantaranya difabel dan berkebutuhan khusus. Difabel adalah singkatan dari different ability atau Different Ability People atau orang yang memiliki kemampuan berbeda yang tidak mempengaruhi kualitasnya dibandingkan manusia lain dengan fungsi fisik yang lengkap. Dengan istilah difabel, masyarakat diajak untuk merekonstruksi nilai nilai sebelumnya, yang semula memandang kondisi cacat atau tidak normal sebagai kekurangan atau ketidakmampuan menjadi pemahaman terhadap difabel sebagai manusia dengan kondisi fisik berbeda yang mampu melakukan aktivitas dengan cara dan pencapaian yang berbeda pula. Dengan pemahaman baru itu masyarakat diharapkan tidak lagi memandang para difabel sebagai manusia yang hanya memiliki kekurangan dan ketidakmampuan. Sebaliknya, para difabel, sebagaimana layaknya manusia umumnya, juga memiliki potensi dan sikap positif terhadap lingkungannya. Penggunaan istilah difabel memberikan perspektif yang lebih baik dibanding penyandang cacat, karena istilah penyandang cacat seolah mempersepsikan sesuatu yang gagal produksi atau abnormal, rusak, tidak dapat diperbaiki lagi. Istilah difabel menunjukkan bahwa seseorang berada dalam kondisi terbatas, terhambat baik untuk sementara maupun permanen dalam menjalankan aktivitas keseharian. Kondisi ini membei peluang untuk mendapatkan perhatian. Dalam arti yang lebih luas difabel juga meliputi ibu hamil, anak-anak, lanjut usia, pengguna kursi roda, kruk, tunanetra, tunarungu, tunadaksa dan sebagainya. ${ }^{9}$ Istilah difabel telah digunakan dalam berbagai peraturan daerah di Indonesia untuk mengganti istilah penyandang cacat. Diantaranya Perda Kota Surakarta Nomor 2 Tahun 2008 tentang Kesetaraan Difabel (Lembaran Daerah Kota Surakarta Tahun 2008 Nomor 2). Peraturan Daerah tersebut kemudian ditindaklanjuti dengan Perwal Kota Surakarta Nomor 9 Tahun 2013 tentang Petunjuk Pelaksanaan Peraturan Daerah Kota Surakarta Nomor 2 Tahun2008 Tentang Kesetaraan Difabel. No 11 Tahun 2002 tentang Penyediaan Fasilitas Pada Bangunan Umum dan Lingkungan Bagi Difabel. Pada Perda ini difabel dimaknai 
sebagai setiap orang yang mempunyai kelainan fisik dan/atau mental, yang dapat mengganggu atau merupakan rintangan dan hambatan baginya untuk melakukan secara selayaknya, yang terdiri dari penyandang cacat fisik; penyandang cacat mental; serta penyandang cacat fisik dan mental. ${ }^{10}$

Istilah difabel dalam Perda Kota Surakarta No 2 Tahun 2008 masih juga dipadankan dan disandingkan dengan istilah penyandang cacat. Ketentuan ini terdapat dalam Pasal 1 angka 8 Perda Kota Surakarta No 2 Tahun 2008. Dari isi Perda Kota Surakarta tersebut nampak bahwa dalam tataran pemerintah telah ada keinginan baik untuk melakukan eufemisme bagi istilah penyandang cacat, namun masih timbul keraguan dalam penggunaan istilah penyandang cacat atau difabel.

Istilah lainnya adalah berkebutuhan khusus. Istilah ini ditemukan dalam Peraturan Menteri Negara Pemberdayaan Perempuan dan Perlindungan Anak No 10 Tahun 2011 tentang Kebijakan Penanganan Anak Berkebutuhan Khusus. Dalam Bab I Pasal 1 angka (2) Permeneg PP dan PA No 10 Tahun 2011 disebutkan bahwa Anak Berkebutuhan Khusus adalah anak yang mengalami keterbatasan/ keluarbiasaan baik fisik, mental-intelektual, sosial, maupun emosional yang berpengaruh secara signifikan dalam proses pertumbuhan dan perkembangannya dibandingkan dengan anak-anak lain seusianya. Istilah ini rupanya selaras dengan Peraturan Menteri Pendidikan Nasional Republik Indonesia No 70 Tahun 2009 tentang Pendidikan Inklusi Bagi Peserta Didik Yang Memiliki Kelainan Dan Memiliki Potensi Kecerdasan Dan/Atau Bakat Istimewa. Pasal 3 ayat (1) dan (2) Permendiknas No 70 Tahun 2009 tersebut mengatur setiap peserta didik yang memiliki kelainan fisik, emosional, mental, dan sosial atau memiliki potensi kecerdasan dan/atau bakat istimewa berhak mengikuti pendidikan secara inklusif pada satuan pendidikan tertentu sesuai dengan kebutuhan dan kemampuannya. Peserta didik yang memiliki kelainan sebagaimana terdiri atas tunanetra; tunarungu; tunawicara; tunagrahita; tunadaksa; tunalaras; berkesulitan belajar; lamban belajar; autis; memiliki gangguan motoric; menjadi korban penyalahgunaan narkoba, obat terlarang, dan zat adiktif lainnya; memiliki kelainan lainnya; maupun tunaganda.

Setelah mencermati isi Pasal 3 Permendiknas No 70 Tahun 2009 jelas bahwa yang dimaksud dengan peserta didik yang memiliki kelainan fisik, emosional, mental, dan sosial atau memiliki potensi kecerdasan dan/atau bakat istimewa adalah anak berkebutuhan khusus seperti dimaksud dalam Pasal 1 angka (2) Permeneg PP dan PA No 10 Tahun 2011. Istilah anak berkebutuhan khusus ini digunakan secara khusus di lingkungan Dinas Pendidikan dan Olah Raga. Penggunaan istilah inipun nampak masih kurang menjunjung harkat dan martabat manusia, dalam hal ini peserta didik karena secara umum dalam bahasa Indonesia kelainan dimaknai sebagai pebedaan, hal (keadaan) yang menyalahi (atau menyimpang dari kebiasaan), atau penyimpangan. ${ }^{11}$ Sementara disabilitas bukanlah suatu keadaan yang menyalahi atau menyimpang dari kebiasaan.

Menurut Convention On The Rights of Persons With Disabilities (Konvensi Mengenai Hak-hak Penyandang Disabilitas) yang telah disahkan dengan UU No 19 Tahun 2011 tentang Pengesahan Convention On The Rights of Persons With Disabilities (Konvensi Mengenai Hak-hak Penyandang Disabilitas), penyandang disabilitas termasuk mereka yang memiliki keterbatasan fisik, mental, intelektual, atau sensorik dalam jangka waktu lama di mana ketika berhadapan dengan berbagai hambatan, hal ini dapat menghalangi partisipasi penuh dan efektif mereka dalam masyarakat berdasarkan kesetaraan dengan yang lainnya. Konvensi ini tidak memberikan batasan tentang penyandang cacat. Pengertian ini ditegaskan dalam Pasal 1 Convention On The Rights of Persons With Disabilities. Dalam konvensi ini penyandang cacat disebut sebagai penyandang disabilitas.

Pasal 1 angka 8 Peraturan Daerah Kota Surakarta No. 2 Tahun 2008 tentang Kesetaraan Difabel (Lembaran Daerah Kota Surakarta Tahun 2008 Nomor 2).

11 Kamus Besar Bahasa Indonesia. 
Istilah penyandang disabilitas dipandang lebih mengakomodasi kondisi riil yang dialami penyandangnya. Hal ini dapat dirujuk pada bagian preambule huruf (e) Convention On The Rights of Persons With Disabilities: "Recognizing that disability is an evolving concept and that disability results from the interaction between persons with impairments and attitudinal and environmental barriers, that hinders their full and effective participation in society on an equal basis with others." Dengan demikian disabilitas dimaknai sebagai suatu konsep yang akan terus berkembang secara dinamis.

\section{Urgensi Penyediaan Dana Bagi Penyan- dang Disabilitas}

Setiap keputusan dibuat oleh badan atau pejabat yang berwenang dengan menggunakan pijakan argumentasi yang memadai. Hal tersebut sangat beralasan karena apabila sebuah keputusan diambil, maka pertimbangan yang digunakan sebagai referensi menjadi ukuran bagi pengambil keputusan apakah yang bersangkutan mempunyai pertimbangan yang masak atau tidak, atau bahkan sewenang-wenang.

Pemberian perhatian terhadap penyandang disabilitas adalah sesuatu yang mendesak. Secara yuridis adanya pengaturan dalam konstitusi mengenai kewajiban negara untuk memelihara fakir miskin, orang-orang terlantar, dan menyelenggarakan jaminan sosial masyarakat menjadikan pemerintah wajib melaksanakan hal tersebut. Secara fundamental tanggung jawab tersebut disebabkan mengingat penyandang disabilitas sering dikategorikan sebagai kaum marginal. Akibatnya penyandang disabilitas sering mendapatkan perlakuan diskriminatif dari masyarakat. Padahal tidak sedikit dari penyandang disabilitas yang sebenarnya sangat memerlukan perhatian khusus sehingga diharapkan dapat hidup mandiri dan lebih baik. Penyandang disabilitas sendiri tentu tidak dalam posisi memilih, untuk dapat menentukan sikap apakah akan hidup mandiri atau memerlukan campur tangan pihak lain. Kenyataan tersebut mesti mendapatkan perhatian serius dari semua pihak termasuk pemerintah.

Labelisasi sosial bagi penyandang disabilitas sebagai pihak yang tidak normal, cacat, dan layak untuk mendapatkan perlakuan yang tidak normal pula sering dijumpai. Padahal sebenarnya sangat mungkin keterbatasan tertentu yang dimiliki seseorang dpat ditutup dengan kelebihan di bidang lain. Ukuran normal dan tidak normal menjadi sesuatu yang relatif, bahkan tidak jelas, seringkali hanya diperuntukkan bagi pihak yang memiliki ketidaklengkapan fisik biologis atau organ tubuh. Sebaliknya pihak yang secara fisik-biologis lengkap, dianggap sebagai orang normal meski terdapat kemungkinan mempunyai kecacatan moral, mentalitasnya lemah, mudah bersikap egois, tidak adil, cenderung mau memperbudak orang lain, menyalahgunakan kekuasaan, dan sikap perilaku negatif yang lainya, tetap saja dianggap sebagai seorang yang normal. Dalam konteks inilah muncul pertanyaan benarkah ukuran dalam memberikan penilaian terhadap orang lain sebagai tidak normal atau cacat tersebut sudah tepat?

Memperhatikan hal tersebut di atas, maka sudah sepantasnya ada perlakuan yang adil dan ada sikap pembelaan terhadap kaum difabel. Salah satu yang bisa dilakukan dengan menyediaan penganggaran memadai bagi mereka. Sejumlah hal dapat dijadikan alasan yang melandasi penyediaan dana bagi penyandang disabilitas yaitu kemanusiaan; keadilan; dan persamaan. Dengan mendasarkan paham kesejahteraan umum sebagai keseluruhan syarat-syarat kehidupan sosial yang diperlukan masyarakat agar dapat sejahtera sekaligus pendapat para ahli ilmu negara maka Franz Magnis Suseno merumuskan adanya tidak tugas utama dari negara, yakni memberikan perlindungan kepada penduduk dalam wilayah tertentu, memberikan dukungan atau memberikan pelayanan secara langsung, dan menjadi wasit yang tidak memihak antara pihakpihak yang berkonflik dalam masyarakat serta menyediakan suatu sistem peradilan yang menjamin keadilan dasar dalam hubungan sosial masyarakat. ${ }^{12}$ 
Pemerintah mesti mengambil sikap yang tepat dalam menghadapi persoalan tersebut. Semua tugas negara tersebut dilaksanakan dengan maksud untuk mewujudkan kesejahteraan masyarakat.

Konsep negara kesejahteraan tidak hanya mencakup deskripsi mengenai sebuah cara pengorganisasian kesejahteraan (welfare) atau pelayanan sosial (social services). Melainkan juga sebuah konsep normatif atau sistem pendekatan ideal yang menekankan bahwa setiap orang harus memperoleh pelayanan sosial sebagai haknya. ${ }^{13}$ Oleh karena itu, meskipun menekankan pentingnya peran negara dalam pelayanan sosial, negara kesejahteraan pada hakekatnya bukan merupakan bentuk dominasi negara, tetapi wujud dari adanya kesadaran warga negara atas hak-hak yang dimilikinya sesuai dengan prinsip-prinsip demokrasi. Negara diberi mandat untuk melaksanakan kewajibannya dalam memenuhi hak-hak warga negara.

Hak-hak warga negara disini tentu saja salah satu yang berhubungan dengan kehidupannya setiap hari adalah hak untuk memenuhi kebahagiaan dan kesejahteraan hidupnya. Dengan demikian negara kesejahteraan mempunyai tanggungjawab untuk senantiasa memperhatikan kebahagiaan dan kesejahteraan masyarakat. Ide dasar negara kesejahteraan dimulai dari abad ke-18 yaitu dipromosikan oleh Jeremy Bentham (1748-1832) bahwa pemerintah memiliki tanggungjawab untuk menjamin the greatest happiness (atau welfare) of the greatest number of their citizens. Bentham menggunakan istilah "utility" (kegunaan) untuk menjelaskan konsep kebahagiaan atau kesejahteraan. Berdasarkan prinsip utilitarianisme yang dikembangkan, sesuatu dapat menimbulkan kebahagiaan ekstra adalah sesuatu yang baik. Sebaliknya, sesuatu yang menimbulkan sakit adalah buruk. Menurutnya aksi-aksi pemerintah harus selalu diarahkan untuk meningkatkan kebahagiaan sebanyak mungkin orang. ${ }^{14}$

Terdapat beberapa permasalahan terkait dengan alokasi anggaran bagi penyandang disabilitas, diantaranya:

Tabel 1.

\section{Beberapa Permasalahan Alokasi Anggaran Bagi Penyandang Disabilitas}

\section{NO PERMASALAHAN \\ REKOMENDASI}

1. Belum tersedianya pusat rehabilitasi yang Program Rehablitasi idealnya tersedia di setiap menyelenggarakan program rehabilitasi dan habilitasi secara komprehensif (aspek sosial, kesehatan, ekonomi, pendidikan) di setiap provinsi.

Provinsi dan diselenggarakan secara menyeluruh termasuk diantaraya harus menyediakan layanan kesehatan, terapi fisik, bimbingan konseling/ psikis, vokasional dan kehidupan sosial dan pendidikan.

2. Rehabilitasi masih selalu dilihat secara medik, sehingga rahabilitasi yang dilakukan sebatas medis. Rehabilitasi sosial sudah dilakukan oleh Kemensos tetapi belum sesuai kebutuhan penyandang disabilitas.

3. Rehabilitasi vokasional yang dilakukan selama ini tidak dijalankan secara serius. Rehabilitasi vokasional dilakukan sebatas pelatihan kerja. Sebenarnya rehabilitasi vokasional juga mencakup vokasional terapi, kemudian sampai pada penempatan kerja, perlindungan terhadap produk dan pemasarannya

Pendampingan harus dilakukan mulai dari pelatihan soft skill, tips interview, sampai pada tahap penempatan kerja, selama bekerja, perlindungan produk dan perlindungan pasar.

$14 \quad$ Ibid., hlm. 58-59.
} 
4. Peraturan mengenai pelaksanaan program CSR (Corporate Social Responsibility) belum mengatur penggunaan dana CSR bagi program pengembangan dan pemenuhan hak-hak penyandang disabilitas, termasuk habilitasi dan rehabilitasi dan Kurangnya sensifitas dari sektor publik dan swasta untuk pengembangan dan pemberdayaan komunitas penyandang penyandang disabilitas dalam hal kesejahteraan social

5. Ketersediaan alat bantu hanya diberikan kepada kepada pemegang ASKES.

6. Produksi alat bantu (kursi roda, tongkat tuna netra, prostetik, orstetik, alat bantu dengar, dll) di Indonesia belum dapat memenuhi kebutuhan para penyandang disabilitas

7. Penyandang diabilitas masihmengalamikesulitan dalam mengakses modal yang diperlukan dalam mengembangkan atau memulai usaha mandiri karena ketiadaan jaminan dan kurangnya kepercayaan atas keberlangsungan usaha yang dilakukan oleh penyandang diabilitas.
Mendukung sektor swasta untuk membuat tindakan-tindakan afirmasi dalam upaya pemenuhan hak-hak penyandang disabilitas melalui program-program CSR, diantaranya dengan menyusun peraturan yang terkait dengan pelaksanaan Program CSR untuk pemberadayaan penyandang disabilitas dan mensosialisasikannya kepada sektor publik dan swasta.

Kebutuhan akan alat bantu tersebut, harus dialokasikan dalam kebijakan nasional dan dalam Anggaran Belanja Negara maupun Daerah

Pemerintah mendorong munculnya kearifan lokal terkait dengan penyediaan alat bantu dengan memanfaatkan sumberdaya lokal.

Adanya program pemerintah yang menjamin perolehan sumber pendanaan pada usaha yang dilaukan penyandang disabilitas melalui program CSR dari berbagai perusahaan baik BUMN, maupun perusahaan swasta

Sumber: Konsorsium Nasional Untuk Hak Penyandang Disabilitas, 2010.

Dari tabel tersebut di atas dapat dilihat bahwa ada sejumlah kebutuhan yang diperlukan oleh penyandang disabilitas. Penyediaan pusat rehabilitasi dan habilitasi merupakan hal yang menarik, mengingat sebenarnya dapat digunakan sebagai instrumen untuk pemberdayaan. Ketersediaan alat bantu yang dapat memberdayakan dan memulihkan kiranya juga sangat diperlukan. Selain itu kebutuhan-kebutuhan lain yang sudah diinfentarisir tersebut memang perlu untuk mendapatkan perhatian. Pemenuhan kebutuhan tersebut memerlukan pendanaan, pemerintah tentu menjadi pihak yang bertanggung jawab baik pemerintah pusat maupun pemerintah daerah, akan tetapi sebenarnya juga dapat mengoptimalkan peran serta masyarakat. Format CSR kiranya menjadi salah satu yang dapat dioptimalkan perannya.

Berdasarkan uraian tersebut di atas, diperlukan adanya pergantian konsep bantuan sosial, karena mindshet bantuan sosial lebih cenderung pada human charity (alasan kemanusiaan). Perlu diketahui bahwa penyandang disabilitas juga memiliki kemampuan dan keahlian yang patut diberikan apresiasi melalui program pemberdayaan di semua aspek dan tidak berdasarkan pada aspek kemiskinan.

\section{Penganggaran Bagi Pemenuhan Hak} Penyandang Disabilitas di Kota Surakarta

Kota Surakarta merupakan salah satu kota di Indonesia yang tergolong maju di dalam memberikan perhatian kepada persoalan penyandang disabilitas. Dasar hukum pengaturan penyandang disabilitas di Kota Surakarta adalah Perda Kota Surakarta Nomor 2 Tahun 2008 tentang Kesetaraan Difabel (Lembaran Daerah Kota Surakarta Tahun 2008 Nomor 2). Peraturan Daerah tersebut kemudian ditindaklanjuti dengan Perwal Kota Surakarta Nomor 9 Tahun 2013 tentang Petunjuk Pelaksanaan Peraturan Daerah Kota Surakarta Nomor 2 Tahun2008 Tentang Kesetaraan Difabel. Kesetaraan difabel adalah kondisi yang menjamin terwujudnya keadilan bagi penyandang disabilitas. Dengan demikian kiranya ada perlakuan yang proporsional di antara para peyandang disabilitas sendiri dan antara 
penyandang disabilitas dengan yang tidak. Dalam Peraturan Walikota tersebut diatur pula mengenai rehabilitasi yang dimaksudkan sebagai upaya yang meliputi semua tindakan untuk mempersiapkan penyandang disabilitas dalam proses integrasi dengan masyarakat. Penyandang disabilitas diberikan hak-hak berupa bantuan sosial sebagai upaya pemberian bantuan kepada penyandang disabilitas yang tidak mampu, yang bersifat tetap, agar dapat meningkatkan taraf kesejahteraan sosialnya, diberikan sarana aksesibilitas fisik yakni kemudahan yang disediakan bagi penyandang disabilitas guna mewujudkan kesamaan kesempatan dalam segala aspek kehidupan dan penghidupan. Bagi penyandang disabilitas diberikan pelayanan hak-hak tertentu meliputi: aksesibilitas fisik; rehabilitasi; pendidikan; kesempatan kerja; peran serta dalam pembangunan; dan bantuan sosial. Aksesibilitas fisik dilaksanakan pada sarana dan prasarana umum yang meliputi : aksesibilitas pada bangunan umum; pada jalan umum; pada pertamanan dan pemakaman umum; dan pada angkutan umum.

Selain penyediaan aksesibilitas dalam sarana umum, dapat pula dilakukan tindakan rehabilitasi. Bentuk tindakan rehabilitasi, sekurang-kurangnya meliputi bidang: medik; mental; pendidikan dan pelatihan; sosial; dan vokasional. Penyandang disabilitas dan/atau kelompok (organisasi) penyandang disabilitas diikutsertakan dalam perencanaan pembangunan di tingkat kelurahan, tingkat kecamatan dan tingkat kota. Selain itu juga dilibatkan dalam perencanaan dan monitoring pembangunan aksesibilitas pada sarana dan prasarana fasilitas umum.

Bantuan sosial diberikan kepada penyandang disabilitas yang masuk kriteria keluarga miskin. Bantuan sosial tersebut dapat berupa uang atau barang sesuai kebutuhan penyandang disabilitas yang bersangkutan. Syarat dan tata cara pemberian bantuan sosial dilakukan oleh satuan kerja perangkat daerah yang ditunjuk oleh Walikota. Berdasar keterangan dari Bagian Sosial Budaya pada Badan Perencanaan Pembangunan Daerah Kota Surakarta ${ }^{15}$ penganggaran untuk keperluan penyandang disabilitas dijadikan satu anggaran dengan persoalan kesejahteraan sosial. Secara teknis penganggaran ada pada SKPD (Satuan Kerja Perangkat Daerah). Dari wawancara dengan salah seorang pejabat pada Bidang Sosial dari Dinas Sosial Nakertrans Surakarta ${ }^{16}$ diketahui bahwa tahun 2015 hibah untuk bidang ini sebesar Rp.1,8 milyar. Hal tersebut belum yang masuk dalam APBNP. Penganggaran pendampingan kegiatan bagi penyandang disabilitas yang rutin dilakukan secara nasional ada HDI (hari difabel nasional).

Sebagaimana dikatakan Franz Magnis Suseno bahwa ada empat prinsip yang menjadi orientasi dari sebuah negara, yakni kesamaan, kebebasan, solidaritas dan manfaat. Negara harus menjamin perlakuan yang sama bagi warganya, memberikan kebebasan bagi warganya akan tetapi juga harus membangun rasa sebangsa dan satu udara (saudara). Selain itu negara juga harus mewujudkan subsidiaritas, yang mendorong kepada yang berlebih membantu yang kekurangan, yang kuat membantu yang lemah, dan yang beruntung membantu yang malang. ${ }^{17}$ Pada masa orde baru sangat terkenal jargon "membangun manusia seutuhnya" yang sebenarnya istilah ini mencemaskan karena meskipun dimaksudkan untuk kehendak yang luhur akan tetapi kurang tepat, karena "membangun" adalah sikap manusia terhadap benda bukan terhadap manusia. Jadi yang dibangun adalah prasarana-prasarana yang memungkinkan manusia berkembang secara utuh. ${ }^{18}$

Disabilitas yang disandang oleh seseorang bukan merupakan sesuatu yang dikehendaki apalagi direncanakan. Akan tetapi seperti yang dikatakan oleh Franz Magnis Suseno tersebut menghendaki

\footnotetext{
Wawancara dengan Aditya Setya Warman, Kasi Anggaran pada DPKKD Kota Surakarta, pada Tanggal 11 Agustus 2015.

Wawancara dengan Didik Adi Putranto, Kabid Sosial pada Dinsosnakertrans Kota Surakarta, Tanggal 20 Mei 2015.

Franz Magnis Suseno, 2001, Etika Politik Prinsip-prinsip Moral Dasar Kenegaraan Modern, Gramedia Pustaka Utama, Jakarta, hlm. 303306.
}

$18 \quad$ Ibid.,hlm.18. 
adanya solidaritas dan subsidiaritas dari sesamanya. Dalam konteks berbangsa maka negara mesti hadir dan memberikan perhatian secara nyata, sehingga negara memberi manfaat bagi warganya termasuk yang dalam kondisi disabilitas. Salah satu yang bisa secara riil diberikan adalah dengan melalui prioritas penganggaran.

Keberpihakan terhadap persoalan tertentu memang dapat dilihat antara lain dalam pengalokasiaan anggaran. Dalam Pasal 31 ayat (4) Undang-Undang Dasar 1945 pasca amandemen juga ditentukan bahwa paling sedikit $20 \%$ dari APBN dianggarkan untuk bidang pendidikan. Di dalam Undang-Undang Nomor 28 Tahun 2009 tentang Pajak Daerah dan Retribusi Daerah diatur mengenai pengalokasian dalam persentase minimal tertentu (earmarking) dari tiga jenis pajak secara langsung terhadap hal-hal yang dibutuhkan rakyat. Minimal 10\% dari hasil Pajak Kendaraan Bermotor digunakan untuk memperbaiki dan membangun sarana transportasi. Minimal 50\% dari hasil Pajak Rokok untuk pelayanan kesehatan dan sebagian dari hasil Pajak Penerangan Jalan digunakan untuk penyediaan sarana penerangan jalan. Dalam pelaksanaannya, praktik earmarking telah berkembang pesat di berbagai negara, baik negara maju maupun berkembang. Di Kolombia, earmarking telah diberlakukan sejak tahun 1921, di mana program kebijakan earmarking ditujukan untuk meningkatkan infrastruktur di daerah (municipal). Di Australia, earmarking yang paling populer adalah Medicare Levy, dimana tujuan dari earmarking ini untuk membantu pembiayaan dalam pelayanan kesehatan.

Dalam teori kebijakan publik, efisiensi penggunaan anggaran bagi pemerintah adalah hal yang sangat penting. Salah satu langkah untuk dapat mencapai efisiensi anggaran Pemerintah menurut ekonom adalah melalui earmarking, yaitu kebijakan pemerintah dalam menggunakan anggaran yang sumber penerimaan maupun program pengeluarannya akan secara spesifik ditentukan peruntukannya. ${ }^{19}$ Menurut Bohari sebuah anggaran yang modern mempunyai ciri yang terlihat dari asasasas: ${ }^{20}$ kelengkapan (velledigheid, universalitas); spesialisasi; berkala (perioditas); formil (bentuk tertentu undang-undang); dan keterbukaan (publisitas). Bohari menambahkan bahwa fungsi anggaran ada tiga hal, yakni fungsi politik, fungsi yuridis, dan fungsi ekonomi. Secara teoretis ada beberapa sistim dalam penyusunan anggaran yang sering digunakan adalah: Traditional Budgeting System; Performance Budgeting System; Planning Programming Budgeting System (PPBS) dan Zero Based Budgeting(ZBB).

Dalam rangka penganggaran bagi kaum difabel, Pemerintah Kota Surakarta menyediaan dana baik untuk kegiatan yang langsung maupun tidak langsung. Penganggaran yang langsung bagi kaum difabel dilaksanakan untuk programprogram bantuan langsung seperti penyediaan alat bantu, penyediaan kebutuhan langsung, maupun pemberdayaan, seperti pelatihan, pemberian ketrampilan, dan pendidikan formal melalui sekolah inklusi. Program tersebut dilaksanakan oleh Dinas Sosial, Tenaga Kerja dan Transmigrasi, maupun oleh Dinas Pendidikan Pemuda dan Olah Raga. Di samping itu juga penganggaran dilakukan untuk kegiatan-kegiatan yang tidak langsung akan tetapi bersifat dukungan. Kegiatan tersebut dilakukan untuk penyediaan sarana umum yang memberikan aksesibilitas bagi kaum difabel, seperti misalnya untuk penyediaan kawasan pedestrian, bangunan pemerintah, trotoar, halte bus, yang memberikan akses bagi kaum difabel. Penganggaran untuk kegiatan tersebut tidak terlihat secara langsung sebagai sebuah mata anggaran, karena menjadi satu dengan kegiaan lain, seperti renovasi gedung pemerintah, pembuatan taman dan kawasan pedestrian, dan pembangunan sarana penunjang transportasi. Penganggaran seperti itu dimasukkan dalam penganggaran SKPD terkait yakni Dinas

\footnotetext{
19 Departemen Keuangan Republik Indonesia, "Kajian Kelayakan Penerapan Earmarking Tax di Indonesia," http://www.fiskal.depkeu. go.id/2010/m/edef-konten-view-mobile.asp, diakses 15 Januari 2015.

20 Bohari, 1994, Hukum Anggaran Negara, Raja Grafindo Persada, Jakarta, hlm. 18-24.
} 
Pekerjaan Umum, dan Dinas Perhubungan.

Penganggaran bagi kaum difabel di Kota Surakarta tidak hanya dilakukan oleh Pemerintah Kota Surakarta saja. Penganggaran untuk mendanai kaum difabel di kota Surakarta juga dibantu oleh Pemerintah Pusat, Pemerintah Provinsi, maupun sumbangan. Dengan demikian penganggaran bagi kaum difabel dapat memenuhi kebutuhan yang setiap tahun terus berkembang, sesuai dengan slogan Surakarta sebagai kota Inklusi dan layak difabel.

Sistem penganggaran yang dilaksanakan oleh Pemerintah Daerah Kota Surakarta pada saat ini menggunakan sistem penganggaran berbasis kinerja. Secara teori anggaran berbasis kinerja merupakan pendekatan penyusunan anggaran berdasarkan beban kerja dan unit cost data ke dalam setiap kegiatan yang terstruktur dalam suatu program untuk mencapai tujuan. ${ }^{21}$ Dasar pemikirannya adalah penganggaran harus dapat digunakan sebagai alat menajemen sehingga penyusunan anggaran harus dapat memberikan hasil yang berguna bagi pengambilan keputusan manajerial (legislatif/eksekutif). Anggaran harus dianggap sebagai program kerja. Anggaran berbasis kinerja memusatkan perhatian pada pengukuran efisiensi hasil kerja dengan tujuan memaksimumkan output yang dapat dihasilkan dari input tertentu. Tiga unsur pokok anggaran berbasis kinerja, yaitu: pengeluaran pemerintah dikelompokkan menurut program dan kegiatan, performance measurement (pengukuran hasil kerja), dan program reporting (pelaporan program). Anggaran berbasis kinerja mempunyai karakteristik tertentu, yakni: klasifikasi anggaran didasarkan pada program dan kegiatan, penekanan pada pengukuran hasil kerja dan bukan pada aspek pengawasan, seetiap kegiatan harus dilihat dari segi efisiensi dengan memaksimalkan output dan memerlukan standar pengukuran hasil kinerja. Anggaran berbasis kinerja mencerminkan maksud dan tujuan permintaan dana, biaya dari program- program yang diusulkan dalam mencapai tujuan ini, data kuantitatif yang dapat mengukur pencapaian serta pekerjaan yang dilaksanakan untuk tiap-tiap program. Penganggaran dengan pendekatan kinerja ini berfokus pada efisiensi penyelenggaraan suatu aktivitas. Efisiensi itu sendiri adalah perbandingan antara output dengan input. Suatu aktivitas dikatakan efisien, apabila output yang dihasilkan lebih besar dengan input yang sama, atau output yang dihasilkan adalah sama dengan input yang lebih sedikit. $^{22}$

\section{Kesimpulan}

Berdasar analisis data yang telah dilakukan diperoleh kesimpulan bahwa Kota Surakarta merupakan salah satu kota di Indonesia yang tergolong maju dalam memberikan perhatian kepada persoalan penyandang disabilitas. Dasar hukum pengaturan penyandang disabilitas di Kota Surakarta adalah Perda Kota Surakarta Nomor 2 Tahun 2008 tentang Kesetaraan Difabel (Lembaran Daerah Kota Surakarta Tahun 2008 Nomor 2). Peraturan Daerah tersebut kemudian ditindaklanjuti dengan Perwal Kota Surakarta Nomor 9 Tahun 2013 tentang Petunjuk Pelaksanaan Peraturan Daerah Kota Surakarta Nomor 2 Tahun2008 Tentang Kesetaraan Difabel. Kebijakan penganggaran bagi penyandang cacat di Kota Surakarta dilakukan dengan menyediakan anggaran terhadap pemberdayaan kaum difabel maupun penyediaan sarana penunjang yang berguna bagi kaum difabel. Penganggaran dilakukan dengan memasukkan ke dalam belanja yang dikelola oleh Dinas Sosial Ketenagakerjaan dan Transmigrasi, Dinas Pendidikan Pemuda dan Olah Raga, Dinas Pekerjaan Umum, dan juga Dinas Perhubungan. Dukungan penganggaran dilakukan oleh Pemerintah Kota Surakarta, Pemerintah Provinsi Jawa Tengah, maupun dari Pemerintah Pusat. Sistem penganggaran yang dilaksanakan oleh Pemerintah Daerah Kota Surakarta pada saat ini menggunakan sistem penganggaran berbasis 
kinerja. Anggaran berbasis kinerja merupakan pendekatan penyusunan anggaran berdasarkan beban kerja dan unit cost data ke dalam setiap kegiatan yang terstruktur dalam suatu program untuk mencapai tujuan

\section{DAFTAR PUSTAKA}

\section{A. Buku}

Bohari, 1994, Hukum Anggaran Negara, Raja Grafindo Persada, Jakarta.

Soekanto, Soerdjono, 1986, Sosiologi Hukum, Universitas Indonesia, Jakarta.

Suseno, Franz Magnis, 2001, Kuasa dan Moral, Gramedia Pustaka Utama Jakarta. ,2001, Etika Politik Prinsipprinsip Moral Dasar Kenegaraan Modern, Gramedia Pustaka Utama, Jakarta.

Suharto, Edi, 2011, Kebijakan Sosial Sebagai Kebijakan Publik, Alfabeta, Bandung.

\section{B. Artikel Jurnal}

WM, Mujimin, "Penyediaan Fasilitas Publik yang Manusiawi Bagi Aksesibilitas Difabel", Jurnal Dinamika Pendidikan, Vol. XIV, No. 1, Mei 2007.

\section{Internet}

Departemen Keuangan Republik Indonesia, "Kajian Kelayakan Penerapan Earmarking Tax di Indonesia," http://www.fiskal.depkeu. go.id/2010/m/edef-konten-view-mobile.asp, diakses 15 Januari 2015.

Departemen Keuangan Republik Indonesia, "Anggaran berbasis kinerja," http://www. anggaran.depkeu.go.id, diakses tanggal 11 Juni 2015.

\section{Peraturan Perundang-Undangan}

Undang-Undang Nomor 4 Tahun 1997 tentang Penyandang Cacat (Lembaran Negara Republik Indonesia Tahun 1997 Nomor 9, Tambahan Lembaran Negara Republik
Indonesia Nomor 3670).

Undang-Undang Nomor 39 Tahun 1999 tentang Hak Asasi Manusia (Lembaran Negara Republik Indonesia Tahun 1999 Nomor 165, Tambahan Lembaran Negara Republik Indonesia Nomor 3886).

Undang-Undang Nomor 11 Tahun 2009 tentang Kesejahteraan Sosial (Lembaran Negara Republik Indonesia Tahun 2009 Nomor 12, Tambahan Lembaran Negara Republik Indonesia Nomor 3886).

Peraturan Pemerintah Nomor 43 Tahun 1998 tentang Upaya Peningkatan Kesejahteraan Sosial Penyandang Cacat (Lembaran Negara Republik Indonesia Tahun 1998 Nomor 70, Tambahan Lembaran Negara Republik Indonesia Nomor 3754).

Peraturan Daerah Kota Surakarta No. 2 Tahun 2008 tentang Kesetaraan Difabel (Lembaran Daerah Kota Surakarta Tahun 2008 Nomor 2).

Peraturan Walikota Surakarta Nomor 9 Tahun 2013 tentang Petunjuk Pelaksana Perda Kota Surakarta No.2 Tahun 2008.

\section{E. Lain-lain}

Konvensi International Hak-Hak Penyandang Cacat dan Protokol Opsional Terhadap Konvensi.

Kamus Besar Bahasa Indonesia.

Wawancara dengan Didik Adi Putranto, Kabid Sosial pada Dinsosnakertrans Kota Surakarta, Tanggal 20 Mei 2015.

Wawancara dengan Aditya Setya Warman, Kasi Anggaran pada DPKKD Kota Surakarta, pada Tanggal 11 Agustus 2015. 